УДК 378.147:57:167:373.5

DOI https://doi.org/10.26661/2522-4360-2021-2-23

\title{
ПІДГОТОВКА МАЙБУТНІХ УЧИТЕЛІВ БІОЛОГІЇ 3 МОЗАЇЧНИМ ТИПОМ МИСЛЕННЯ ДО ДОСЛІДНИЦЬКОЇ ДІЯЛЬНОСТІ У ЗАКЛАДАХ ЗАГАЛЬНОЇ СЕРЕДНЬОЇ ОСВІТИ
}

\author{
Солона Ю. О. \\ кандидат педагогічних наук, \\ викладач кафедри біології людини та імунології \\ Херсонський державний університет \\ вул. Університетська, 27, Херсон, Україна \\ orcid.org/0000-0001-5181-8177 \\ yusolona@ukr.net \\ Сидорович М. М. \\ доктор педагогічних наук, \\ професор кафедри біології людини та імунології \\ Херсонський державний університет \\ вул. Університетська, 27, Херсон, Україна \\ orcid.org/0000-0003-1302-3378 \\ marinasidorovich1@gmail.com
}

\begin{abstract}
Ключові слова:
професійна підготовка, фундаменталізачія змісту освіти, дослідницька діяльність, дослідницька компетентність, структура дослідницької компетентності.
\end{abstract}

\begin{abstract}
Аналіз нормативних документів та сучасної науково-педагогічної літератури засвідчив, що професійна підготовка майбутніх учителів біології - це проблема, яка активно розробляється за різними напрямами. Її домінуючим аспектом є організація дослідницької діяльності здобувачів вищої освіти. Базовим складником такої організації розглядається формування їхньої дослідницької компетентності Тому першочерговим завданням підготовки майбутнього вчителя, зокрема біології, до дослідницької діяльності у закладах загальної середньої освіти є цілеспрямоване формування такої якості особистості. Воно забезпечується проектуванням відповідної діяльності здобувачів під час фахової підготовки. Відібрано педагогічні умови такого проектування під час підготовки майбутніх учителів біології. Їх провідну частину склали дидактичні умови, що безпосередньо пов’язані iз психолого-педагогічними умовами. Провідними засадами конструювання процесу формування дослідницької компетентності такого фахівця на сучасному етапі розвитку суспільства $є$ фундаменталізація освіти і зміни у типі мислення учнівської молоді, зокрема майбутніх учителів біології. Розроблено структурно-функціональну модель підготовки майбутніх учителів біології до дослідницької діяльності у закладах загальної середньої освіти для реалізації вказаних засад. Вона складається із взаємопов’язаних цілемотиваційного, змістово-процесуального і контрольно-оцінного блоків. Центральною ланкою такої моделі $є$ система методичних прийомів. Вона забезпечує взаємозв'язок провідних рис «кліповості» мислення здобувачів і сукупності відповідних принципів адаптивного навчання. Модель розглядається як провідна складова частина конструювання освітнього середовища для формування дослідницької компетентності майбутніх учителів біології.

Реалізація моделі традиційними, нетрадиційними методами навчання i різноманітними засобами інформаційно-комп'ютерної підтримки забезпечується розробленим дидактичним доробком.
\end{abstract}




\title{
MODERN APPROACHES OF TRAINING FUTURE TEACHERS OF BIOLOGY TO RESEARCH ACTIVITIES IN GENERAL SECONDARY EDUCATION INSTITUTIONS
}

\author{
Solona Yu. O. \\ Candidate of Pedagogical Sciences, \\ Lecturer at the Department of Human Biology and Immunology \\ Kherson State University \\ University str., 27, Kherson, Ukraine \\ orcid.org/0000-0001-5181-8177 \\ yusolona@ukr.net \\ Sidorovich M. M. \\ Doctor of Pedagogical Sciences, \\ Professor at the Department of Human Biology and Immunology \\ Kherson State University \\ University str., 27, Kherson, Ukraine \\ orcid.org/0000-0003-1302-3378 \\ marinasidorovich1@gmail.com
}

Key words: professional training, fundamentalization of educational content, research activity, research competence, structure of research competence.

\begin{abstract}
The analysis of normative documents and modern scientific and pedagogical literature showed that the professional training of future biology teachers is a problem that is being actively developed in various areas. Its dominant aspect is the organization of research activities of higher education students. The basic component of such an organization is the formation of their research competence. Therefore, the primary task of preparing future teachers, in particular biology, for research activities in general secondary education is the purposeful formation of this quality of personality. It is provided by designing the relevant activities of applicants during professional training. The pedagogical conditions of such design during the training of future biology teachers are selected. The leading part of them were didactic conditions that are directly related to psychological and pedagogical conditions. The leading principles of constructing the process of forming the research competence of such a specialist at the present stage of development of society are the fundamentalization of education and changes in the type of thinking of future biology teachers. The structural and functional model of preparation of future biology teachers for research activities in general secondary education institutions is designed to implement these principles. It consists of interrelated goal-motivational, content-procedural and control-evaluation blocks. The central link of such a model is a system of methodological techniques. It provides a link between the leading features of the "clip" thinking of applicants and a set of relevant principles of adaptive learning. The model is considered as a leading component of designing the educational environment. It is aimed at forming the research competence of future biology teachers.
\end{abstract}

Постановка проблеми. На всіх етапах розвитку суспільства питання якісної підготовки педагогічних кадрів завжди було пріоритетним. Воно $\epsilon$ нагальним і в сучасному освітянському просторі. Така потреба спричинена низкою чинників, які стосуються суспільного й державного замовлення. Одним із провідних напрямів професійної підготовки майбутніх учителів, які зможуть прийняти виклики сьогодення, $є$ реалізація дослідницької парадигми. Орієнтація на дослідницький тип навчання проголошена в низці нормативно-правових актів держави, що орієнтує заклади вищої освіти (3ВО) на підготовку здобувачів для впровадження іiї в майбутній професії. Виходячи зі структури педагогічної діяльності [14], напрямами реалізації такого підходу $є$ формування 
дослідницької (гностичної) функції майбутнього вчителя. Як засвідчив власний огляд вказаної проблеми $[12 ; 13]$, учені одностайні в тому, що формування дослідницької (гносеологічної) функції учителя у ЗВО повинне відбуватися насамперед за рахунок цілеспрямованої організації відповідної діяльності здобувачів у ЗВО. Провідним аспектом упровадження дослідницької парадигми в підготовку вчителів $€$ реалізація одного 3 принципів фундаменталізації освіти, зокрема iї змісту [5; 10]. Грунтовному розробленню цього питання щодо професійної підготовки майбутніх учителів біології (МУБ) присвячені нечисленні праці науковців [11; 16]. Аналіз науково-методичної літератури 3 позиції сутності поняття «фундаменталізації змісту освіти» засвідчив недоопрацьованість впровадження фундаменталізації змісту освіти засобами проєктування ДД МУБ під час вивчення дисциплін системної біології. Окрім вищевказаного, ще однією перешкодою щодо успішної реалізації вищевказаного $\epsilon$ суттєве підвищення рівня інформатизації суспільного життя, що зумовило виникнення особливого мозаїчного, або «кліпового», типу мислення в сучасної молоді. Особливості вказаного феномену містить праця [15]. Цей аспект досліджуваної проблеми стосовно підготовки МУБ до дослідницької діяльності у 3ЗСО не знайшов відображення у працях науковців. Водночас анкетування майбутніх учителів біології в п'яти ЗВО України виявило тенденцію до збільшення в них кількості здобувачів-«кліповиків». Виходячи 3 цього, виникає нагальна потреба щодо вдосконалення підготовки МУБ шляхом обов'язкового врахування мозаїчності їхнього мислення. Отже, моделювання адаптивного освітнього середовища, яке, з одного боку, забезпечувало би фундаменталізацію змісту підготовки сучасних здобувачів (майбутніх учителів біології) засобами організації ДД, а 3 іншого - орієнтувалося б на особливості їх мислення, $є$ актуальною проблемою.

Мета статті полягає в теоретичному обгрунтуванні та експериментальній перевірці структурно-функціональної моделі підготовки майбутніх учителів біології до дослідницької діяльності у закладах загальної середньої освіти в процесі вивчення фахових біологічних дисциплін, яка базується на вище вказаних засадах.

Виклад основного матеріалу статті. Аналіз нормативних документів МОН і грунтовних науково-методичних праць [1; 7 тощо] засвідчив, що ДД повинна стати провідною складовою частиною роботи сучасного вчителя у З3СО. Базисною складовою частиною такої діяльності вчителя $є$ наявність у нього дослідницької компетентності (ДК) [3]. Тому підготовка фахівців, зокрема майбутніх учителів біології, до ДД у 33СО, повинна насамперед бути спрямована на формування їх ДК [ 8].
Грунтовний аналіз науково-методичних праць, наприклад Т. Ваколя [2], Л. Карпова [3] та інших, дозволив виокремити у складі компонентів структури ДК майбутніх учителів біології мотиваційний, операційний, когнітивний та рефлексивний компоненти. У процесі такої самої аналітичної роботи відібраний склад провідних елементів кожного $з$ указаних компонентів цієї структури ДК. Розроблену структуру в МУБ розглядали у дослідженні як інструментарій для виміру динаміки іiі формування у процесі їх професійної підготовки в ЗВО. Поелементний склад її компонентів - базис для розроблення критеріїв та показників виміру ефективності створеного дидактичного доробку.

Як вже було вказано вище, проєктування ДД майбутніх учителів - це один із провідних аспектів упровадження фундаменталізації змісту їх підготовки. Водночас фундаменталізація загалом вбачає насамперед формування «фундаментально-знаннєвого каркасу» як основного теоретичного базису професійної підготовки МУБ [9]. Такий каркас створюється засобами викладання фундаментальних освітніх компонентів із біології [11]. Отже, ДК майбутніх учителів біології необхідно формувати насамперед засобами саме таких дисциплін. До їх складу віднесено клітинну біологію (цитологію + молекулярну біологію), генетику, еволюціонізм й загальну екологію. Діагностика проблеми формування ДК майбутніх учителів біології на практиці засвідчила певний ступінь іiі недоопрацьованості відповідно до сучасної освітянської державної політики та теоретичного доробку фахівців. Виникає необхідність теоретичного обгрунтування й розробення структурно-функціональної моделі такої підготовки, яка забезпечила б позитивну динаміку формування ДК вказаних фахівців. Під час iii розроблення обов'язковою умовою стало врахування тенденції посилення «кліповості» мислення учнівської молоді. Аналітична робота 3 відповідною психологічною літературою, наприклад [15], дала змогу виокремити провідні риси такого мислення, більшість 3 яких можуть бути враховані шляхом організації адаптивного навчання [4]. Ефективним підходом його організації є проєктування продуктивної, зокрема навчально-дослідницької. діяльності [6]. 3 метою створення адаптивного освітнього середовища здійснили аналіз відповідної науково-методичної літератури [17] та результатів пілотного дослідження. Він дав змогу визначити дидактичні умови як провідні, що безпосередньо пов'язані з психолого-педагогічними умовами, зокрема феноменом «кліповості» мислення МУБ. До їх складу віднесено сполучення традиційних та інноваційних методів навчання; упровадження в освітні процес різновидів комп'ютерного, хмарного, мобільного навчання 
та їх сполучення; реалізацію системи методичних прийомів щодо організації ДД здобувачів із мозаїчним типом мислення засобами адаптивного навчання; впровадження системи прийомів організації роботи здобувачів під час самостійної підготовки за фахом, що враховує особливості їх мисленнєвих процесів; здійснення систематичного моніторингу та відповідної корекції процесу формування означеної якості. Для реалізації вказаних педагогічних умов у підготовці майбутніх учителів біології розроблено структурно-функціональну модель, яка складається з трьох блоків.

Ціле-мотиваційний блок актуалізує мету розроблення структурно-функціональної моделі через потребу суспільства в підготовці вчителя-дослідника, зміни в типі мислення (явище «кліповості») сучасних здобувачів вищої освіти та фундаменталізацію освіти. Мета в свою чергу зумовлює добір складових частин теоретико-методологічного базису підготовки МУБ. До нього входять адаптивний, системний, особистісно-діяльнісний, компетентнісний підходи та фундаменталізація змісту освіти, загальнодидактичні (науковості, доступності, послідовності та неперервності) та специфічні (творчої активності, продуктивності, професійної спрямованості та адаптивного навчання) принципи навчання.

Змістово-процесуальний блок містить методи, форми та засоби навчання, реалізація яких забезпечується системою методичних прийомів проєктування ДД під час вивчення системної біології. Саме вона й зумовлює взаємозв'язок принципів адаптивного навчання та рис «кліповості» мислення під час організації такої ДД у змісті освітніх компонентів системної біології (рис. 1). Вказана система містить 20 методичних прийомів, серед яких заповнення фактичних, смислових, логічних прогалин у вивченому понятті, явищі з різних джерел інформації; формування алгоритму відповіді на порівняння та інші логічні операції (аналіз, синтез, абстрагування, спостереження, експеримент); «метод парадоксів», «мозковий штурм», «прес», «метод проєктів», «дискусія», «дебати», «мікрофон», «кейс-метод», метод випадковостей, помилок та асоціацій; використання індивідуально-дослідницьких завдань із використанням засобів інформаційної підтримки; проблемно-пошукові завдання в межах дисциплін системної біології, для виконання яких здобувач здійснює всі етапи наукового дослідження: постановка проблеми, висунення гіпотез, аналіз проблемної ситуації та нестандартне іiі вирішення; дослідницькі проби; прийоми інформаційно-пошукової та аналітико-синтетичної діяльності (прийоми кваліфікаційного аналізу - «кваліфікаційної реконструкції», «матричного оперування», «виділення зв'язку»); моделювання ситуацій у рольових іграх; створення творчого продукту; відповідь запитанням на запитання, аргументом на аргумент під час використання методів доведення та переконання; створення коротких слайд-презентацій, кінофрагментів, візуальних рядів; створення блок-схем та інших графічних образів (кластерів, фреймів) тощо. Упровадження в освітній процес більшості з них здійснювалось за допомогою різних засобів інформаційної підтримки: електронного лабораторного практикуму (віртуальна біологічна лабораторія), навчальних посібників, методичних рекомендацій, навчальних матеріалів сайту «Цитоекологія», хмарно-орієнтовної технології та освітнього ігрового ресурсу мобільного навчання. Ефективність реалізації педагогічних умов у попередньому блоці моделі доведена значеннями критеріїв і параме-

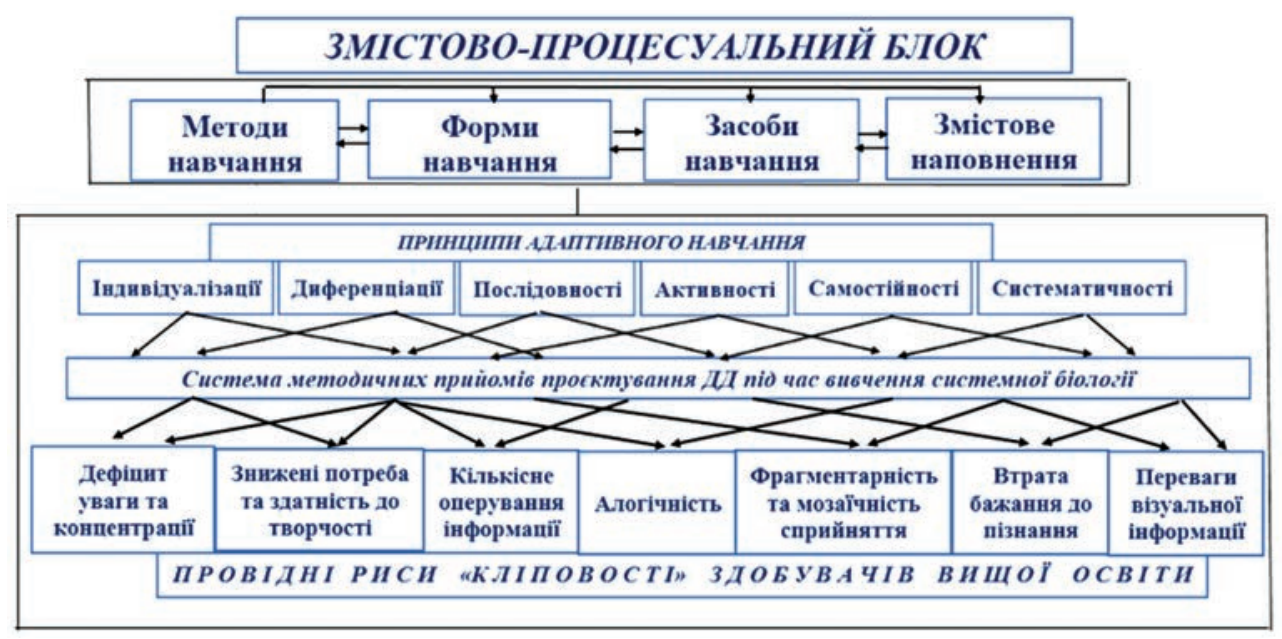

Рис. 1. Змістово-процесуальний блок структурно-функціональної моделі підготовки майбутніх учителів біології до ДД у З3СО 
трів іiі контрольно-оцінного блоку. Вони дозволили виміряти результат формування вказаної компетентності за низьким, середнім і достатнім рівнями. Результати експериментальної перевірки ефективності цієї моделі містить рис. 2.

Вони свідчать про позитивну динаміку рівнів сформованості ДК у МУБ за розробленою структурно-функціональною моделлю порівняно 3 чинною системою підготовки таких фахівців. Так, чисельність здобувачів 3 низьким рівнем сформованості ДК (СДК) стосовно всіх ії компонентів значно зменшилася. Водночас кількість студентів 3 достатнім і високим рівнями СДК зросла. При цьому 1,5-2 рази збільшився відсоток здобувачів 3 достатнім рівнем цього показника. Вказане знайшло статистично достовірне відображення у зростанні загального показника СДК в МУБ з 0,62 до 0,72.

Висновки. Проведене дослідження дало змогу зробити такі висновки:

1. Базисною основою підготовки майбутнього вчителя біології до здійснення ДД $є$ формування його ДК, структура якої містить мотиваційний, когнітивний, операційний та рефлексивний компоненти. Компоненти в свою чергу складаються 3 низки елементів, які використано для розроблення критеріїв та показників виміру вказаної якості особистості.

2. Провідними засадами конструювання процесу формування ДК такого фахівця на сучасному етапі розвитку суспільства $є$ фундаменталізація освіти і зміни у типі мислення майбутніх учителів біології.

3. Для реалізації вказаних засад у дослідженні розроблено структурно-функціональну модель підготовки майбутніх учителів біології до ДД у 33СО, що складається із взаємопов'язаних цілемотиваційного, змістово-процесуального і контрольно-оцінного блоків.
4. Центральною ланкою такої моделі є система методичних прийомів, яка забезпечує взаємозв'язок провідних рис «кліповості» мислення здобувачів і сукупності відповідних принципів адаптивного навчання, за якими організується їх підготовка. Вона розглядається як провідна складова конструювання освітнього середовища для формування ДК у МУБ.

5. Упровадження вказаної системи забезпечує відповідну реалізацію провідних дидактичних умов, які безпосередньо пов'язані з психолого-педагогічними умовами, зокрема феноменом «кліповості» мислення здобувачів вищої освіти.

6. Для реалізації розробленої системи методичних прийомів підготовлено та апробовано навчально-методичне забезпечення: навчальний посібник «Цитологія 3 основами молекулярної біології» дослідницької спрямованості; навчально-методичний посібник «Інформаційна підтримка шкільного курсу біології у закладах загальної середньої освіти»; пам'ятка сучасному здобувачу вищої освіти 3 особливостями мисленнєвих процесів для самостійної підготовки до занять за фахом; пам'ятка викладачу щодо викладання фахових дисциплін здобувачам-кліповікам; навчальна програма спецкурсу «Особливості навчання біології учнів з мозаїчним типом мислення» для підготовки майбутніх учителів біології.

7. Результати педагогічного експерименту розробленої структурно-функціональної моделі підготовки МУБ до дослідницької діяльності у З3СО засвідчили іiі ефективність.

Подальшим напрямом науково-методичного пошуку є плідне розроблення методичного забезпечення для впровадження структурно-функціональної моделі у підготовку здобувачів із системної біології та інших фахових дисциплін.

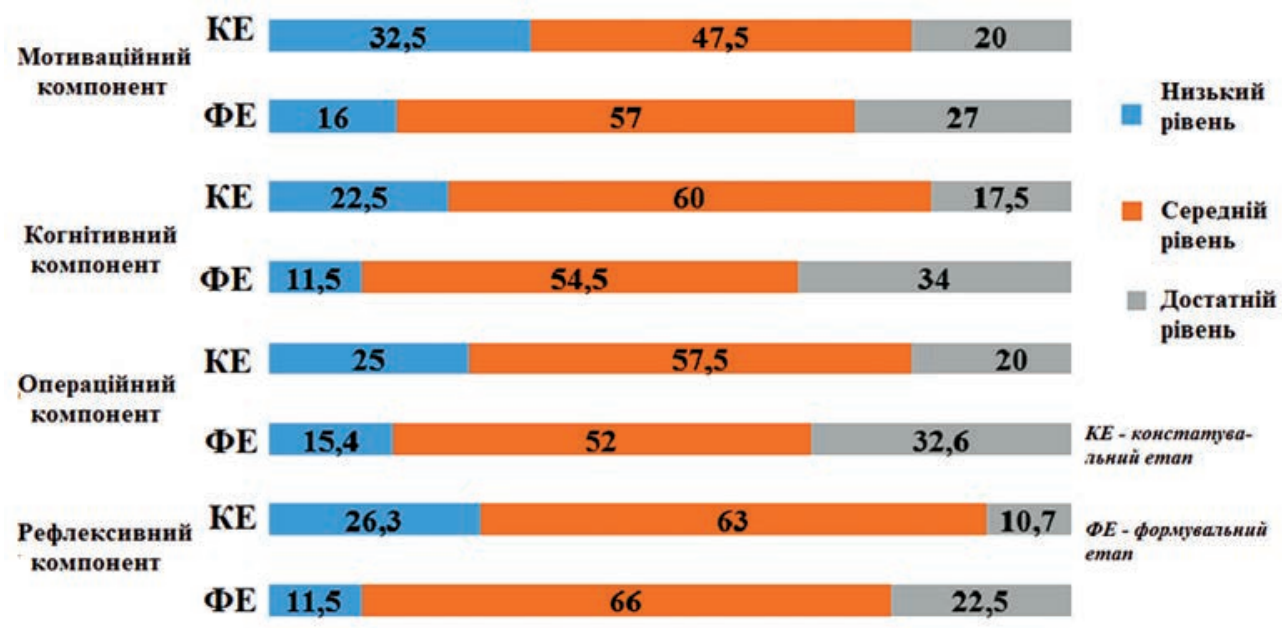

Рис. 2. Динаміка розподілу майбутніх учителів біології за рівнями сформованості ДК як результат педагогічного експерименту 


\section{ЛІТЕРАТУРА}

1. Антонюк Л.В. Формування готовності майбутніх вчителів фізико-математичних спеціальностей до навчально-дослідницької діяльності: дис. ... канд. пед. наук: 13.00.04 / Вінницький державний педагогічний університет імені Михайла Коцюбинського. Вінниця, 2014. 258 с.

2. Ваколя T.I. Формування дослідницької компетентності майбутніх учителів початкових класів у процесі професійної підготовки: автореф. дис. ... канд. пед. наук : 13.00.04 / Херсон. держ. ун-т. Херсон, 2014. $20 \mathrm{c}$.

3. Карпова Л.Г. Структура дослідницької компетентності вчителя. Наукові записки кафедри педагогіки. 2019. Випуск 44. С. 127-139.

4. Літвінова М.Б. Методична система адаптивного навчання фізики у закладах вищої технічної освіти: дис. д-ра пед. наук: 13.00.02 / Центральноукраїнський державний педагогічний університет ім. В. Винниченка. Кропивницький, 2018. 517 с.

5. Луценко Г.В. Компетентнісний підхід до науково-дослідної роботи студентів як елемент фундаменталізації фізичної освіти. Вища освіта України. 2012. № 3 (46). Т. 3. С. 80-89.

6. Лозицкий В.Л. Феномен клипового мышления и информационно-комуникационные технологии в высшем професиональном образовании. Научные труды Респуб. института высшей школьы. 2016. С. 375-379.

7. Москалюк Н.В. Формування дослідницький умінь майбутніх учителів природничого профілю в процесі вивчення біологічних дисциплін: дис. ... канд. пед. наук: 13.00.04 / Тернопільський національний педагогічний університет ім. В. Гнатюка. Тернопіль, 2013. 287 с.

8. Пташенчук О.В. Формування дослідницької компетентності майбутніх учителів біології у процесі професійної підготовки: дис. ... канд. пед. наук: 13.00.04 / Сумський державний педагогічний ун-т ім. А.С. Макаренка. Суми, 2018. 347 с.

9. Рудишин С.Д. Фундаменталізація біологічної освіти в педагогічному університеті у вимірах сталого розвитку : офіційний сайт. URL: http://pfm.gnpu.edu.ua/index.php/16-naukova-d/47-naukovashkola-rudyshyna-serhiia-dmytrovycha. (дата звернення 20.05.2021).

10. Семеріков С.О. Фундаменталізація навчання інформатичних дисциплін у вищій школі: монографія. Кривий Ріг: Мінерал, 2009. 339 с.

11. Сидорович М.М. До питання вдосконалення фундаментальної підготовки майбутніх вчителів біології. Фактори розвитку педагогіки і психології в XX столітті. Збірник тез Між.наук.-парк. конф. Харків:Східноукраїнська організація «Центр педагогічних досліджень», 2019. С. 77-80.

12. Сидорович М.М. Дослідницька функція вчителя: сучасний погляд. Актуальні проблеми сучасної освіти та науки в контексті євроінтеграційного поступу : матеріали доп. учасн. VII Міжнар. наук.-практ. конф. Луцьк : ЛІРоЛ, 2021. С. 97-100.

13. Сидорович М.М., Солона Ю.О. Формування дослідницької компетентності - обов'язкова складова підготовки майбутніх учителів біології до дослідницької діяльності у школі .Modern education systems in the USA, the EU and the post-Soviet countries. Seattle: KindleDP, 2020. C. 205-208.

14. Сластенин В.А., Исаев И.Ф., Шиянов Е.Н. Педагогика. Учеб. пособие для студ. высш. пед. учеб. Заведений. Под ред. В.А. Сластенина. М.: Издательский центр "Академия", 2013. 576 с.

15. Тоффлер Э. Шок будущего. М.: АСТ, 2002. 557 с.

16. Харченко Л.Н., Горовая В.И., Сотникова Н.Н. Современное биологическое образование. Теоретический и технологический аспекты: монография / за ред. Л.Н. Харченко. Ставрополь: Ставропольсервисшкола, 2005. 320 с.

17. Хриков С.М. Педагогічні умови в структурі наукового знання. Шлях освіти. 2011. № 2. С. 11-15.

\section{REFERENCES}

1. Antoniuk, L.V. (2014). Formuvannia hotovnosti maibutnikh vchyteliv fizyko-matematychnykh spetsialnostei do navchalno-doslidnytskoi diialnosti [Formation of readiness of future teachers of physical and mathematical specialties for educational and research activity]. (Candidate's thesis). Vinnytsia State Pedagogical University named after Mykhailo Kotsyubynsky. Vinnitsa [in Ukrainian].

2. Vakolia, T.I. (2014). Formuvannia doslidnytskoi kompetentnosti maibutnikh uchyteliv pochatkovykh klasiv u protsesi profesiinoi pidhotovky [Formation of research competence of future primary school teachers in the process of professional training]. (Extended abstract of candidate's thesis). Kherson State University. Kherson [in Ukrainian].

3. Karpova, L.H. (2019). Struktura doslidnytskoi kompetentnosti vchytelia [The structure of the teacher's research competence] Naukovi zapysky kafedry pedahohiky, 44, P. 127-139. [in Ukrainian].

4. Litvinova, M.B. (2018). Metodychna systema adaptyvnoho navchannia fizyky u zakladakh vyshchoi tekhnichnoi osvity [Methodical system of adaptive teaching of physics in institutions of higher technical 
education]. (Doctor's thesis). Central Ukrainian State Pedagogical University named after V. Vinnichenko. Kropyvnytskyi [in Ukrainian].

5. Lutsenko, H.V. (2012). Kompetentnisnyi pidkhid do naukovo-doslidnoi roboty studentiv yak element fundamentalizatsii fizychnoi osvity [Competence approach to research work of students as an element of fundamentalization of physical education] Higher education in Ukraine, 3 (46), 3. P. 80-89 [in Ukrainian].

6. Lozitskiy, V.L. (2016). Fenomen klipovogo myshleniya i informatsionno-komunikatsionnyye tekhnologii v vysshem profesionalnom obrazovanii [The phenomenon of clip thinking and information and communication technologies in higher professional education] Scientific works of the Republic of the Institute of Higher Education, P. 375-379 [in Russian].

7. Moskaliuk, N.V. (2013). Formuvannia doslidnytskyi umin maibutnikh uchyteliv pryrodnychoho profiliu $v$ protsesi vyvchennia biolohichnykh dystsyplin [Formation of research skills of future teachers of natural sciences in the process of studying biological disciplines]. (Candidate's thesis). Ternopil National Pedagogical University named after V. Hnatyuk. Ternopil [in Ukrainian].

8. Ptashenchuk, O.V. (2018). Formuvannia doslidnytskoi kompetentnosti maibutnikh uchyteliv biolohii u protsesi profesiinoi pidhotovky [Formation of research competence of future biology teachers in the process of professional training]. (Candidate's thesis). Sumy State Pedagogical University named after A.S. Makarenko. Sumy [in Ukrainian].

9. Rudyshyn, S.D. Fundamentalizatsiia biolohichnoi osvity $\mathrm{v}$ pedahohichnomu universyteti u vymirakh staloho rozvytku. (2021). Ofitsiinyi sait pryrodnycho-matematychnoi osvity Hlukhivskoho natsionalnoho derzhavnoho universytetu. [Official site of natural and mathematical education of Glukhiv National State University]. Retrieved from http:// pfm.gnpu.edu.ua/index.php/16-naukova-d/47-naukova-shkolarudyshyna-serhiia-dmytrovycha/ [in Ukrainian].

10. Semerikov, S. (2009). Fundamentalizatsiia navchannia informatychnykh dystsyplin u vyshchii shkoli [Fundamentalization of teaching computer science disciplines in higher education]. Krivoy Rog: Mineral [in Ukrainian].

11. Sydorovych, M.M. (2019). Do pytannia vdoskonalennia fundamentalnoi pidhotovky maibutnikh vchyteliv biolohii [On the issue of improving the fundamental training of future biology teachers], Faktory rozvytku pedahohiky i psykholohii v XX stolitti, materialy Mizhnarodnoi naukovo-praktychnoi konferentsii [Factors in the development of pedagogy and psychology in the XX century]. Kharkiv [in Ukrainian].

12. Sydorovych, M.M. (2021). Doslidnytska funktsiia vchytelia: suchasnyi pohliad [Teacher's research function: a modern view], Aktualni problemy suchasnoi osvity ta nauky v konteksti yevrointehratsiinoho postupu, materialy Mizhnarodnoi naukovo-praktychnoi konferentsii [Current problems of modern education and science in context European integration procedure]. Lutsk [in Ukrainian].

13. Sydorovych, M.M., Solona, Yu.O. (2020). Formuvannia doslidnytskoi kompetentnosti - oboviazkova skladova pidhotovky maibutnikh uchyteliv biolohii do doslidnytskoi diialnosti u shkoli [Formation of research competence is a mandatory component of training future biology teachers for research activities at school], Suchasni systemy osvity v SShA, YeS ta postradianskii krainia, Proceedings of the Conference. [Modern education systems in the USA, the EU and the post-Soviet countries] [in USA].

14. Slastenyn V.A., Ysaev Y.F., \& Shyianov E.N. (2013). Pedahohyka [Pedagogy]. M.: Academy [in Ukrainian].

15. Toffler, E. (2002). Shok buduschego [Shock of the future]. M.: AST [in USA].

16. Harchenko, L.N., Gorovaya, V.I., \& Sotnikova, N.N. (2005). Sovremennoe biologicheskoe obrazovanie. Teoreticheskiy i tehnologicheskiy aspektyi [Modern biological education. Theoretical and technological aspects]. Stavropol: Stavropolservisshkola [in Russian].

17. Khrykov, Ye.M. (2011). Pedahohichni umovy v strukturi naukovoho znannia [Pedagogical minds in the structure of scientific knowledge]. Shliakh osvity, 2. P. 11-15 [in Ukrainian]. 